\title{
Reinterpreting Paul's perspective of celibacy in 1 Corinthians 7 in light of singlehood amongst Nigerian Christians
}

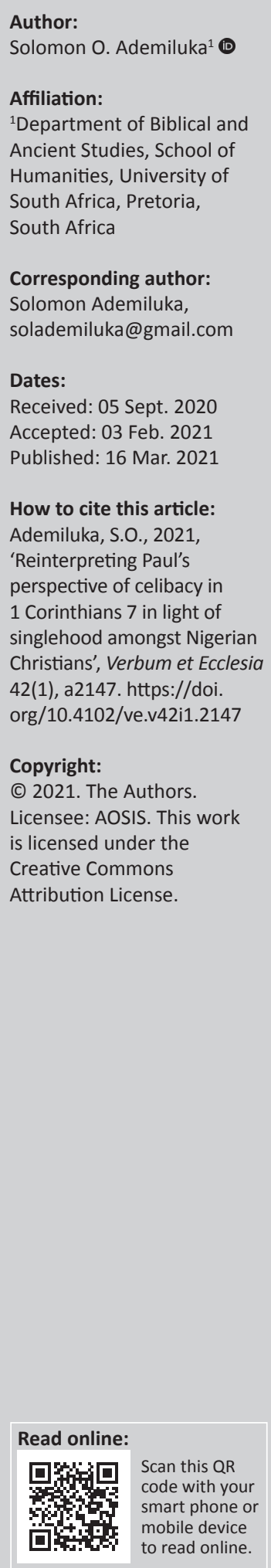

In Nigeria, the rate of involuntary singlehood among women has since been on the increase. While marriage at about the age of 30-35 is not considered late for men, most often a lady is expected to be married at 25-27 years of age, and when it is not so, the life of the woman concerned is largely characterised by desperation for marriage. The article attempted a reinterpretation of Paul's perception of celibacy in 1 Corinthians 7 considering the Nigerian Christians' attitude to involuntary singlehood. In essence, it sought the possibility of accommodating celibacy as an accepted Christian alternative to marriage. Using the descriptive approach, the author gathered and utilised material relevant for the constraints of singlehood in Nigeria as well as the reinterpretation of celibacy in the Nigerian context. The article employed the exegetical method for the study of 1 Corinthians 7 in relation to marriage and celibacy. The article found that Nigerian single women live their lives in desperation for marriage. The situation of Nigerian singles is compounded by the general negative attitude of the church which considers marriage, as against celibacy, to be the normal course for Christians. The work concluded that Paul's position in 1 Corinthians 7 gives room for a Christian sexuality which values celibacy as of equal status with marriage. The church in Nigeria should develop a sexual theology that accepts sexuality in this way. In this way, marriage and celibacy become complimentary to each other in the pursuit of the church's mission.

Intradisciplinary and/or interdisciplinary implications: This research involved the disciplines of the New Testament and Christian Ethics. It reinterpreted Paul's perspective of celibacy in 1 Corinthians 7 in the Nigerian context. The article postulated that a sexual theology based on this perspective would enable Nigerian Christian singles to see singlehood as a possible calling to serve God.

Keywords: singlehood; marriage; celibacy; 1 Corinthians 7; sexual theology.

\section{Introduction}

The term 'singlehood' refers to 'the state of being single and especially unmarried' (Webster 2020a). In Nigeria, involuntary singlehood has thus become a matter of concern to many people, especially amongst the womenfolk. One major reason for late marriage or non-marriage is the downward turn of the economy over the years, which has rendered most male youths unemployed. Whilst many men marry above the age 30 , most often when a lady is $25-27$ years of age and is yet to have a steady suitor, it becomes a matter of concern, not only to her but also to her parents and relatives. Women affected in this way go through a life that is largely characterised by a feeling of incompleteness and the desperation to get married. At the end, a large number of them involuntarily remain unmarried. As many of these women are members of the church, singlehood becomes a challenge to the church. The church cannot afford to close its eyes to this problem because it is worth its name only when it shares in the secular problems of its members (Mangayi 2014:135). Unfortunately, the church seems to remain blind to the reality of nonmarried Christians in its fold. It is yet to learn how celibacy 'can serve as a dynamic, life-giving mode of existence for contemporary followers of Christ' (Varnell 2016:2). In the Merriam Webster Dictionary (Webster 2020b) and Dictionary.com (2020), celibacy refers to the state of not being married or abstinence from sexual relations and/or marriage usually for religious reasons. According to Barrett (1971), 'celibacy is the state of voluntarily being unmarried, sexually abstinent, or both, usually for religious reasons' (cited in Ekpendu 2016:1). It is in this regard that this article envisages that in order to make its witness relevant to the life situation of involuntary Christian singles, the church in Nigeria can respond to the challenge of singlehood through a 
reinterpretation of Paul's idea of celibacy in 1 Corinthians 7 wherein celibacy is not restricted to the priesthood.Therefore, the article attempts a reinterpretation of Paul's perception of celibacy in light of Nigerian Christians' experience in terms of singlehood. In other words, it seeks the possibility of accommodating celibacy as an accepted Christian 'alternative social reordering' in Nigeria outside the confines of the priesthood (Frahm-Arp 2012:371). The target population is Christian involuntary singles, especially women. It employs the descriptive approach for the elucidation of the constraints of singlehood in Nigeria, the historical reflection on marriage and celibacy, as well as the reinterpretation of celibacy in the Nigerian context. The work uses the exegetical method for the study of 1 Corinthians 7 in relation to marriage and celibacy. It begins with the constraints of singlehood amongst Nigerian Christians, from which it proceeds to the exegesis. The essay then discusses in historical perspective the attitude of the church towards marriage and celibacy. Finally, it postulates a sexual theology by the church in Nigeria to adapt Paul's conception of celibacy to the Nigerian Christian context.

\section{The constraints of singlehood amongst Nigerian Christians}

As mentioned above, the term 'singlehood' refers to 'the state of being single and especially unmarried' usually for religious reasons (Webster 2020a). In the words of Oderinde (2013), it is:

[A] situation when a person who has reached the state of maturity in every facet of life is not married, probably as a result of unavailability of spouse or some other factors. (p. 167)

When applied to women:

[Singlehood] describes older never married women, who are past conventional age for marriage [which] varies across cultures and socio-economic classes. Nonetheless, because most women marry for the first time in their 20s, many demographers and family scholars use the age marker of 30 or 35 years to distinguish younger never married women from spinsters. In societies where marriage is strongly associated with motherhood, marriage after age 30 , which is the upper limit of the most fecund years, for women, is considered late. (Ntoimo 2012:1)

According to Bellani, Esping-Andersen and Nedoluzhko (2017:54), 'lifelong singles are ... individuals who have not experienced a co-residential partnership (either marriage or cohabitation)'. Amongst most ethnic groups in Nigeria, marriage for females is usually expected before or at age 30 , by which time reasonable pressure for marriage would have begun to mount on the singles concerned (Isiugo-Abanihe 2000; NPC 2009, both cited in Ntoimo 2012:2). Oderinde (2013:168) observes that 'pushing the age of marriage into the late thirties and higher is now an increasing trend in the [Nigerian] society'. Isiugo-Abanihe (2000) also attests to the 'increase in female age at first marriage among certain sociocultural groups in Nigeria' (cited in Ntoimo 2012:2). One major reason for late marriage for both men and women in Nigeria is the downward turn of the economy over the years, which has rendered most male youths unemployed. Without stable jobs, most 'young men do not have the necessary resources to pay [the bride price]' and to cater for family (Zwang 2004:30; cf. Oderinde 2013:168). Ntoimo (2012) captures the situation aptly when she states:

$[M]$ ore and more men continue to have their first marriage at later ages. Over 60 percent of men in Nigeria first marry after age 25 . Considering the average spousal age difference of between two to ten years in Nigeria, women who are ready for marriage would have to wait longer to marry. (p. 86)

The women's situation in this regard is made more complex by the transformation from the traditional pattern by which the choice of spouse was made by parents to the more individualistic pattern based on love and self-selection, especially for educated and urban women' (Ntoimo 2012:1). Added to this is the fact that a woman has to wait for men to ask her hands in marriage, as the 'culture prohibits a woman from making the first move' (Agazue 2016:7). However, there are other nuptial behaviours on the part of young women which cause delay in marriage or nonmarriage. According to Oderinde (2013:168), some of them get delayed in the course of pursuing 'higher career development and educational attainment'. Others take undue time to enjoy spinsterhood, believing that being married would rob them of the enjoyment (p. 169). Some young women rely on divine guidance for the choice of marriage partners, most often waiting for 'vision, prophecy and dreams alone. So they wait endlessly to see vision or dream about the right man' (p. 168).

In Nigeria, as in Africa at large, the general attitude towards singles, especially women, is not at all pleasant. As the society has the perception (Baloyi 2010):

$[T]$ hat every normal person must get married ... remaining a single person in this context becomes one of the most difficult decisions of one's life. [A] single adult person is not only unacceptable, but he/she also becomes a bad example in the community. (p. 725)

Single persons 'are seen as negating the norms of femininity, ... stigmatized and seen as having moral or spiritual problems' (Ntoimo \& Isiugo-Abanihe 2013:11). Oderinde (2013:169) opines that 'unmarried adults are often viewed as either unserious or as having some problems'. Unmarried women are usually avoided by the married, treated with disdain and looked upon as pitiable people (p. 169). They are often placed on watch by married women, suspecting that they might be making advances to their husbands (Baloyi 2010:735).

It is no surprise, then, that most unmarried women do have the withdrawal syndrome, amongst other psychological problems. According to Koons and Anthony (1991), ‘[t]hey very often will withdraw into themselves, into their homes, and become reclusive, rejecting all attempts of others to reach out to them' (p. 115). Oderinde (2013:169) notes inferiority 
complex, self-pity and self-withdrawal as some of the challenges faced by single women, particularly in relating with their married counterparts. Similarly, Manasra (2003) affirms that women who are unable to marry 'might feel useless, hopeless, worthless, and desperate [which] could lead to self-pity, self-hatred, and negative self-esteem' (p. 424). The situation of a single woman's desperation can be illustrated with Frahm-Arp's (2012:377) conversation with one who 'broke down in tears, asking, "When will it be my turn for someone to love me?"' Manasra states that a single woman's self-evaluation is usually negative, as she believes that there is something wrong with her that keeps men away. Single women's negative self-evaluation might manifest in psychological distress such as being:

$[N]$ ervous, easily irritated, impulsive, irrational, reckless, and having destructive behavior ... [T] his behaviour is indicative of aggression towards the social and physical environment [and] ... reflects [their] frustration and dissatisfaction with their lives and their families. (Manasra 2003:425)

Shuzhuo et al. (2010) are therefore correct when they state that:

[S]inglehood is a state of frustration, and even of deprivation, for which it is difficult to find socially acceptable compensations, [being excluded from] having children, living with a partner, having sexual relations. (p. 679)

In a culture, like that of Nigeria, in which it is the man who must make the move to find a wife, whilst single men may approach women to seek their hands in marriage, the main method by which single women attempt to change their status is by seeking divine intervention. ${ }^{1}$ In this regard, Agazue (2016) notes that single 'women face double jeopardy' for obvious reasons. The first one is the fact that the 'biological clock' seems to tick faster for women and thus puts them 'under intense pressure to get married as soon as possible'. Secondly:

The culture that prohibits childbearing outside marriage or single parenting affects women more than men. This makes women more desperate for marriage because they may not want to bear the shame associated with childbearing outside marriage or single parenting. If a man impregnates a woman outside marriage, the woman bears greater consequences than the man. For example, the woman is the one to carry the pregnancy and bring up the child with her resources and in her own home whilst the man may remain almost invisible. Whilst some people may see the man as irresponsible, the woman is seen not only as irresponsible but also as a 'whore'. (p. 7)

In Nigeria, as in many parts of Africa, the attitude of the church generally to the problem of singlehood is to encourage affected persons to keep praying and being hopeful for their right partners. Thus, 'in a world in which getting married is difficult, the ... churches preach a promising message: by being faithful ... God will bless women with ideal husbands' (Frahm-Arp 2012:377). Beyond

1.One is aware that these days, single men and women do advertise themselves on radio and television as well as social media for marriage, but this is yet to be popularly accepted method of getting marriage partners in Nigeria. this, the church lacks a sexual theology that caters for its unmarried members (Varnell 2016:49).

In Nigeria, single women are oftentimes not persuaded by the abstract encouragement to keep praying and hoping, but rather prefer to patronise certain divine avenues. Seeking for a husband through divine intervention comes against the backdrop of the perception that having delay in marriage, like any other misfortune is a spiritual problem. According to Oderinde (2013):

It is believed that the [persons affected] have been cursed, maybe by man or spirits, for one reason or the other. Some are believed to have relationships with some invisible personalities, [such as] spiritual husbands or spiritual wives, and may not be able to get married in the physical realm until such relationships are broken through prayers and special deliverance. (p. 168)

Cashing in on such women's belief 'that they are spiritually chained [and] can only attract their life partners through divine means, some pastors and prophets have exploited many unmarried women both financially and sexually' (Agazue 2015:22). It should be noted, however, that sometimes single women's sexual relation with 'men of God' may be one way for such women to fulfil their natural sexual desire rather than a means of sexual exploitation on the part of the men. This is because, as Baloyi (2010:726) rightly observes, one way by which some single women cope with their sexual desires is 'having multiple sexual relationships'. Singlehood thus constitutes an enormous challenge to women 'to re-evaluate [their] ethics, moral standards and values concerning sexual behavior' (p. 733).

Nigerian women's desperation to get married is thus explicable against the background of African traditional belief that everyone must get married, the belief that is often also supported with biblical texts such as Genesis 2:18, 24 . Whilst the exegesis of these passages is not within the scope of this article, it is pertinent to mention that many interpreters have plausibly argued that none of them supports the argument of marriage for all (e.g. Agana 2018:90-110). Moreover, a reinterpretation of Paul's conception of celibacy in 1 Corinthians 7 as being contemplated in this essay will get Christian women better enlightened to see desperation for marriage unnecessary. In anticipation of the reinterpretation, the section below attempts an exegesis of the 1 Corinthians passage in relation to marriage and celibacy.

\section{Corinthians 7 in relation to marriage and celibacy: An exegesis}

In 1 Corinthians 7, Paul states, 'Now concerning the matters about which you wrote, it is well for a man not to touch a woman' (v. 1, RSV ${ }^{2}$ ). The Greek phrase $\mu \eta \alpha \pi \tau \varepsilon \sigma \theta \alpha$ is thus rendered by the RSV literally as 'not to touch', 'which

2.The English Bible versions used in this article are abbreviated as follows: Revised Standard Version (RSV); New International Version (NIV); Today's English Version (TEV). 
connotes the idea of having sexual intercourse' (Ademiluka 2019:5). However, in this context, the term is better translated as 'not to marry' (as in the NIV and TEV) in view of verse 2, where the author advises everyone to marry 'because of the temptation to immorality' (RSV). Thus, Paul here responds to the Corinthian Christians' enquiries on matters having to do with the desire for abstinence from marriage (Baumert 1996:26). It can be deduced from the chapter that all categories of members of that church, married people (vv. 1-5, 10-16), single people (6-9) and engaged people (25-40) wanted answers to how to 'respond to the spiritual impulse towards abstinence' (Baumert 1996:27; cf. Ademiluka 2019:5). Paul explains that the Christians should marry to avoid sexual immorality, as in marriage they can rightfully enjoy sexual intercourse (vv. 2- 5; cf. Fitzmyer 2008:274). Paul wishes that 'all were as I myself am' (v. 7, RSV), but because they may not have the gift of self-control as he, they may go ahead and marry (vv. 7-9).

There are divergent views on what Paul wishes in verse 7. Some argue that what he wishes for all is not the unmarried state but continence. According to Ellicott's Commentary for English Readers, Paul's 'words do not mean that the Apostle wished that everyone was unmarried, but that everyone had the same grace of continence which he himself was endowed with' (Bible Hub 2004-2020). As another source puts it, Paul:

$[W]$ ould be glad if all people had control over their passions and propensities as he had ... and could abstain from marriage when circumstances of trial, etc., would make it proper. (Barnes' Notes on the Bible, cited in Bible Hub 2004-2020)

Thus, according to this source, the wish for self-control is to enable one to abstain from marriage if occasion calls for abstinence. This view finds support in Adam Clarke Commentary that 'Paul wished that all [the members of the Corinthian] church were unmarried like himself [for the sake of] the necessities of the Church' (Studylight.org 2001-2020). It is therefore plausible to suggest that the wish for selfcontrol is to serve the purpose of abstinence from marriage, which in turn would enable the celibate to serve the church better. It is therefore incorrect to say that what Paul wishes in 1 Corinthians 7:7 is not celibacy, but self-control, because in this context the two are inseparable. It may be correct, then, to say that Paul 'had tasted the [value] of the celibate life, and was desirous that others should' taste it (Bengel's Gnomen, cited in Bible Hub 2004-2020), or, as Fiore (2003:228) puts it, to imitate Paul's way of life. This means that, for Paul, it is not that marriage is a $\sin$ (v. 28), but 'but celibacy is better' (Castelli 1999:227; cf. Moss \& Baden 2015:171). '[T]he single life is better than the married life, but the married life is better than fornication' (King 2011:5). As Barrett (1968) puts it, in Paul's rating, 'the most fortunate state is that of the unmarried person who is under no pressure to marry; less desirable is that of the person who must express his sexual nature and does so within marriage' (cited in Burden 2005:14).

Some interpreters observe that Paul prefers celibacy for Christians on two grounds (King 2011:5-7; Reed 2013:73). Firstly, it is better to remain single in view of the imminent eschaton (v. 26), and secondly, celibacy will enable them to be fully devoted to God's service (vv. 32-34). In verse 26, Paul says there is a 'present crisis' ( $\varepsilon v \varepsilon \sigma \tau \omega \sigma \alpha v \alpha v \alpha \gamma \kappa \eta v)$, which is explained in verse 31 in terms of the form of this present world ... passing away' (RSV). But it should be noted that the reference to the eschaton here is applicable only to the betrothed members of the Corinthian church (vv. 25-40). Paul says that in view of the imminent end of the world, it is preferable for them not to consummate marriage with their partners; however, they are free to do as they wish (Ademiluka 2019:8; King 2011:6). Moreover, Paul has made it clear that he was single (v. 7), which could not be linked to his view of the eschaton. And throughout the chapter, he does not hide his preference for the celibate life for Christians (vv. 1, 7-8, 38). Therefore, the principal reason for Paul's preference is found in verses $32-34$. Celibacy is preferable for Christians because it will enable them to be fully devoted to God's service, free from worldly anxieties (Collins 1999:296). Nonetheless, Paul's preference of celibacy over marriage is explicable in the context of later stoicism and Jewish asceticism (Collins 1999:255; Deming 2004:54). His idea that marriage was necessary for those who could not control themselves sexually 'and would need release, echoed the sentiment of ancient medics and Romans in general, for whom an excess of blood boiled sperma required a legitimate outlet' (Moss \& Baden 2015:189). Hence, in choosing marital affairs 'over patronage of prostitutes, Paul blended together biblical morality and Stoic sexual ethics or Jewish asceticism' (p. 190). Plato's well-known idea of marriage and sex as a distraction may also have influenced Paul's relation of matrimony to worldly anxieties (p. 190). This suggestion seems to be reflected by Keener (1993) when he states that:

[A] number of groups of philosophers and minor [Jewish] religious sects ... advocated celibacy or the rejection of marriage. [To them] marriage is a distraction and should never be undertaken by the wise man except in the rare instances where one might find a spouse equally devoted to the philosophic life. (p. 466)

Paul's preference for celibacy was thus being influenced not only by his idea of the eschaton and devotion to God's service, but also by his religio-philosophical context. Celibacy as conceived by him, therefore,need not be restricted to the priesthood, the fact which can also be deduced from the text. When Paul wishes all to be like himself (v. 7), he could not have had only the church leaders in mind, that is, all here refers to the entire membership of the Corinthian church. It is necessary to point out, although, that Paul does not envisage that all Christians would be celibates. Rather, he left room for both celibacy and marriage (Burden 2005:16; cf. v. 28). Varnell (2016:17) is relevant here when he states that Paul laid emphasis on both marriage and celibacy as 'gifts and legitimate ways of life [and thus] laid the groundwork that other thinkers would build upon'. As will be seen in the next section, particularly from the Reformation onwards the church subsequently after Paul seems to have thus understood celibacy, that is, as not being for the clergy alone 
and a matter of choice for Christians. This proposition supports the possibility of a contextual reinterpretation as being suggested in this article. Moreover, Paul's recommendation of celibacy proves that the Bible does not make marriage an obligation for all. And this conclusion is in keeping with 'the larger biblical picture [which presents] marriage as optional, on practical (1 Cor 7:2, 9, 26), personal (v. 39), religious (vv. 32-34) and missiological (Mt 19:12) grounds' (Agana 2018:107). The historical reflection below shows how the church interpreted and reinterpreted Paul on marriage and celibacy.

\section{A historical reflection on the attitude of the church towards marriage and celibacy}

Jesus made reference to those who voluntarily choose celibacy on account of their devotion to God's work in Matthew 19:12 but certainly, mandatory abstinence from marriage was not part of his message. Voice of Faith (n.d.) recognises that 'many of the early disciples were married and even traveled with their wives' (p. 1; cf. 1 Cor 9:5), which demonstrates that the 'apostles, like other Christians, have a right to be married' (McKnight 1969, cited in Ekpendu 2016:32). O'Loughlin (2013:202) states that 'from what can be gleaned from the scanty references to ministers in the earliest Christian documents, it is clear that there was no notion of celibacy'. This was in keeping with the Jewish culture in respect to attitude to marriage. However, in the second century CE, the membership of the nascent church 'became increasingly Greek and Roman, [and] the local leadership drew upon ... the Greek and Roman culture' to base its worship (Voice of Faith, p. 1). In turn, this gentile culture drew upon the views of philosophers such as Pythagoras, Plato, Plotinus and the Stoics with their 'contempt for the human condition and hatred of the body [which] was a disease endemic in the entire culture of the period' (Dodds 2011, cited in Voice of Faith, p. 1). Hence, Graeco-Roman:

$[P]$ riests abhorred the body, denigrated women, and avoided marriage. [In fact,] many even castrated themselves to flee from the temptations of the flesh. Pagan asceticism [thus] became a competitor to Christian spirituality. (Voice of Faith, p. 2)

Christian thinkers of this period like Athenagoras, Justin Martyr, Tatian, Tertullian and Origen drew heavily on this heathen philosophy, and then passed it on to Christianity (Voice of Faith, p. 3). For example, Justin Martyr was against sexual intercourse apart from the purpose of procreation, whilst Origen believed that celibacy was better for Christians than marriage (Voice of Faith, p. 3). In the second and third centuries, some of the Apocryphal Acts (e.g. the Acts of Paul and Thecla) taught that celibacy was superior to marriage, depicting 'their heroines as defying family, fiancés, and husbands in their attempts to commit themselves to Christian chastity' (Clark 1996:3). In this way, Christian spirituality was being explicitly identified with the renunciation of sexual relations. Noteworthy in this period, however, is the personality of Clement of Alexandria (150-215) who 'viewed celibacy as an unmanly evasion of responsibility [querying if it was] not permitted for both the married person and his partner to care for the things of the Lord' (Voice of Faith, p. 3).

In the fourth century 'the first signs of disquiet about the compatibility of marriage and priesthood' began to emerge (O'Loughlin 2013:202). At the Council of Elvira in Spain (c. 310), it was decreed that 'all clerics having a position in the ministry are ordered to abstain completely from their wives and not to have children', and anyone who flouted this order was to be deposed (Voice of Faith, p. 3). In 386, the Elvira decree was reinforced by the Council of Rome, and it was declared that intercourse was defilement (Voice of Faith, p. 4). The writings of a group of influential thinkers helped to reinforce the position of the church, as they 'held that celibacy was a higher spiritual condition than marriage and that the cultic purity of the priest required abstinence from sexuality' (O'Loughlin 2013:203). Jerome (c. 347-419) was the prime advocate of the ascetic movement which gained ground in Western Christianity during the course of the 380s. In his writings, Jerome 'encouraged aristocratic women to adopt lives of celibacy' (Clark 1996:42). He compared virginity, widowhood and marriage, giving 'virginity a numerical value of 100, widowhood 60 and marriage 30' (Ozment 1993, cited in O'Reggio 2012:200). In the early 390s, Jerome wrote to counteract the views of Jovinian (d. 405) who had praised the value of marriage, rating it equal in status with celibacy 'if the married person led a virtuous life in other respects' (p. 42).

Perhaps, the most influential Christian thinker of this period was Augustine (354-430), Bishop of Hippo in North Africa (Voice of Faith, p. 4). In his early life, Augustine belonged to the Manichean group who held the dualistic realism that God or spirit was good whilst creation or matter was bad. When he converted to Christianity, Augustine was still influenced by his Manichean ideas. For instance, early in his conversion, he held the view that 'the basic sin of man ... was sexual expression' (Voice of Faith, p. 4). In his response to the dispute on marriage and celibacy between Jerome and Jovinian, Augustine 'composed treatises that struck a middle ground in the debate [conceding] the superiority of virginity but nonetheless upheld the goodness of marriage' (Clark1996:43). According to Augustine, marriage 'is a good since it is a good to beget children ... but it is better not to marry, since it is better for human society itself not to have need of marriage' (p. 52). Men and women who have adopted celibacy should not consider marriage as an evil. After all, Paul said, 'And if you take a wife, you have not sinned. And if a virgin marries, she has not sinned' (1 Cor 7:28), and '... he who marries his betrothed does well; and he who refrains from marriage will do better' (v. 38). Therefore, those who 'choose the greater gifts [should] not condemn [those who choose] the lesser' (pp. 52, 65).

Throughout the Middle Ages, the church in the Latin West maintained the anti-marriage attitude, and 'predictably 
moved towards a completely celibate priesthood and spawned numerous celibate religious orders' (Burden 2005:9). This attitude 'became inbred in clerical education until finally, in the 12th century, the Latin Church legislated mandatory celibacy' (Voice of Faith, p. 5). As O'Loughlin (2013) puts it,

In a series of synods leading up to two councils held in Rome Lateran I (1123) and Lateran II (1139) - the marriages of clergy were declared not only unlawful, but null and void. The law stated that anyone in Orders could not marry, and someone married could only become a priest if the marriage were set aside (i.e. they no longer lived as husband and wife, but the wife could not re-marry) (original emphasis). (p. 205)

Although less forceful, in the Greek East, a strong tradition of celibacy had also been present. Burden (2005:10) opines that in 691, the Second Council of Trullo had set a different course for the churches in the East when it allowed sexual relations for married clergy, at a time when their counterparts in the West were not permitted to have sexual relations. Vaverek (2005) further clarifies on the differences in adherence to celibacy between the Western and Eastern churches. He explains that:

$[I] t$ is only that part of the Catholic Church whose cultural origins are in Western Europe, called the Latin or Western Rite, which requires candidates for priestly ordination to be single. Catholics of the numerous Eastern Rites, whose distinct cultural roots are in Eastern Europe, North Africa, the Middle East or parts of India, have retained the ancient custom of allowing married men to be ordained as priests. Because exploration, immigration and evangelisation spread primarily from Western Europe, the Latin Rite expanded its territory and numbers far more than did the Eastern Rites. The Latin Rite is consequently much better known than the Eastern Rites, and people often mistakenly believe that the Catholic Church universally forbids married priests. (p. 23)

By the 16th century, the law on celibacy was well established, an entirely celibate priesthood having been made canon law at the 1563 Council of Trent (Burden 2005:10). It is important to mention, although, that 'in many places [the law] was ignored or by-passed', evidenced in the well-known practice of priests keeping wives in the name of housekeepers (O'Loughlin 2013:206). It is in light of such:

$[A]$ buses of the vow of chastity by everyone from parish priests to cardinals to popes that the Reformers began imagining and articulating a new understanding of marriage and celibacy in Christian life. (Varnell 2016:32)

Varnel1 states that the Reformers sought a reform from the Catholic sexual ordering that seemed to them contrary 'to the actual realities of sexual life' (p. 32). They accepted celibacy as a calling of God but rejected any imposition of it 'on women and men, such as was done in the priesthood and monastic orders'.

Perhaps, the most influential figure of the Reformation was Martin Luther (1483-1546). Luther condemned celibacy, describing it as the creation of canon law, which was itself the work of the devil. Going by his own understanding of 1 Corinthians 7:9, 'for fallen men, burning with passion, marriage was a necessity if they were to avoid sin' (Varnell 2016:207). By virtue of this conviction, even having taken the vow of celibacy as a monk, Luther got married in June 1525, and explicitly encouraged fellow priests to get married, thereby 'repudiating their vows of celibacy' (O'Reggio 2012:204). For Luther, priests should be free to marry because 'God has not bound them and no one else ought to bind them' (p. 204). Luther saw marriage as God's special gift to man because 'the woman [Eve] was given to the man as a companion in all things but particularly to bear children' (p. 202). For this reason, marriage should not be despised but adored and sanctified. Marriage surpasses all other social estates; it is 'the most common and noblest estate, which pervades Christendom and extends through the entire world' (p. 203). At the same time, Luther saw celibacy as the nobler gift than marriage but both as equal before God. Whilst marriage 'is a common gift to all, [chastity] is a gift reserved for the few' (p. 207). Marty (2008) draws attention to the significance of the influence of Martin Luther when he states that by the 16th century:

[T] he law of celibacy ... was so deeply etched in the minds of the faithful, and so strongly did the church leaders insist on it that to question it and to promote clerical marriage struck very close to social foundations of the church and government. (cited in O’Reggio 2012:210)

Yet, this was what Luther did. Through his efforts, 'marriage had moved from a base containment system for sinful desire, to the highest of virtues' (Agana 2018:92). Following through with Luther's approach, John Calvin (1509-1564) saw to the outlawing of the monastic system in Geneva and to the establishment of 'social and legal regulations for the practice of marriage as a social institution' (Witte 2009, cited in Agana, p. 92). Thus, with Luther's influence on the German culture and Calvin's on Genevan law, 'a new era in which marriage was a highly esteemed divine estate began' (p. 92).

The Reformation, then, gave birth to a tradition in the Protestant churches with negative attitudes towards the celibate life, attitudes which have continued to date. Amongst the Protestants, the pendulum has long swung away from celibacy to marriage so much so that 'marriage is often considered to be the only normal course for adult Christians' (Burden 2005:15). The general message seems to be that marriage is good whilst celibacy is bad (Agana 2018:93). Marriage is viewed as 'the key to happiness, selfrealization, fulfillment, and intimacy and to deny marriage is to prevent an individual from achieving their full potential as a person' (Varnell 2016:51). In Africa particularly, as Agana puts it:

Cultural pressure merges with such superlative views of the sanctity and usefulness of marriage within much of Christian theology, and the result ... is that celibacy and singleness are often frowned upon. (p. 92)

This description is illustrative of the Nigerian context, which indicates that there is little space for Nigerian Christians who would voluntarily want to choose the celibate life. 
From the church, the 'only one logical response to anyone with any sexual desire [is that] they should embrace their sexual desire and marry' (p. 51). In the words of Agana (2018), 'Many pastors and ministers, in line with the cultural economy, preach that marriage and procreation are obligatory upon all unless they are physically or mentally impaired' (p. 93).

Nonetheless, it is important to note that in the history of the church, celibacy has been criticised particularly because of its abuse, but no one has condemned it as unnecessary for the church's mission. Rather, as seen above, most writers on celibacy rated it equal to or even higher than marriage as a religious estate. More important for the purpose of this article, however, is the involvement of lay members of the church as celibates. Vaverek (2005) states that:

[I]n Catholic and Orthodox life the most significant celibate group is not the clergy. It is in the life of consecrated laypeople that this practice has had its most remarkable flourishing and offered its greatest inspiration. Such consecration, through a vow of perpetual chastity, is lived individually (hermitic life) or communally (cenobitic life). These souls place themselves at the service of God and neighbour either through a secluded ministry of prayer or through a life of prayer coupled with outreach ministries such as teaching, health care, evangelisation, etc. (p. 23)

Vaverek (2005:23) finds examples of such consecrated lives in the religious orders such as the Benedictines, Dominicans and Franciscans. In recent times, they are represented in missionaries such as 'the Missionary Brothers and Sisters of Charity founded by Mother Theresa of Calcutta'. Such groups and individuals have made tremendous contributions to the mission of the Church, some of which culminated in 'our great houses of prayer, our schools and universities, our hospitals and social services, or our historic missionary achievements'. Celibacy, therefore, is an act of giving oneself to God and neighbour, and should not be seen as concerned only with the priesthood. This observation makes the reinterpretation of Paul's perception of celibacy to be of much relevance in the Nigerian context. The reinterpretation provides a context for the church to expand its theology on marriage to cater for its single members. In the section below, this article considers the need for the church in Nigeria to develop a sexual theology to achieve this purpose.

\section{Reinterpreting Paul's perspective of celibacy in the Nigerian context}

In the reinterpretation of Paul's idea of celibacy in Nigeria, the church has a major role to play. In the first instance, the church has to align itself with the proper biblical perspective on Christian sexual living. In other words, it has to change its impression that marriage is an all-important status that is mandatory for all Christians. Then, the church should develop a Christian sexual theology that recognises marriage and celibacy as equal social estates for Christians. Varnell (2016) has rightly observed that:
[I]n its assumptions of a hypersexual culture that assumes the be-all, end-all of marriage and sexual expression ... the church lacks a sexual, marital and familial theology that makes sense of women and men who are not married ... Singles have been pushed to the fringes of the church, receiving little in the way of theological sustenance for their sexual lives, [and has thus] ... lost out on the valuable witness celibates [can] offer to the church. (pp. 2, 49-50)

Therefore, the church in Nigeria needs to:

$[R]$ eimagine and reinvigorate sexual theology [and] reclaim a vision of celibacy for 21st century Christians. [In this way,] the church will be better able to speak a living word to women and men as they seek to live [their] sexual lives in conformity with the Gospel of Christ. (Varnell 2016:2)

A sexual theology that gives equal recognition to marriage and celibacy is in conformity with Paul's idea of Christian sexuality in that he left room for both, indicating that both are necessary for the mission of Christi's church in a complimentary manner:

[C]omplementary missionary advantages of hospitality for married couples and mobility for singles ... Thus both Christian marriage and Christian singleness are necessary for a full expression of [the] Christian mission. (Burden 2005:16, 17)

In this way, ' $[t]$ ogether in distinct ways, celibacy and marriage provide the church with important means of witness and mission to the world' (Vaverek 2005:25). In Nigeria, through a sexual theology that recognises celibacy as equal to marriage, the church will be in a position to exploit the situation of its single members for the purpose of its mission to the society. Through this theology, the church would have taught these members that singlehood does not put them at any disadvantage as Christians. Rather, it gives them the opportunity to be gladly 'married' to God's service. Reinterpreting Paul's perception of celibacy in this way, Nigerian Christians are being taught to see singlehood no more as a misfortune but a possible calling into God's service. This understanding of celibacy will also help to reduce the stress with which Nigerian Christian singles, especially women, seek to marry by all means.

These and many more are the advantages that would accrue to the church in Nigeria by developing a sexual theology that places marriage and celibacy on equal grounds. The facts of this theology will have to be imparted particularly to the youth groups in the church in order to begin to get their minds disabused of the traditional belief that marriage is mandatory for all. When singles are advised on getting suitable mates, such advice should be balanced with the admonition that celibacy is equally good. In those denominations where women are ordained into the leadership cadre, there must not be discrimination against single women; they 'must also be allowed to take leadership roles just like all other women' (Baloyi 2010:740). They must be made to participate in all church programmes like their male counterparts and married women. The church's doctrine, all preaching and teaching on marriage hitherto 
will now have to incorporate the facts on the value of celibacy and its equality with marriage, and all such facts should be reflected in its relevant manuals and programmes.

\section{Conclusion}

In Nigeria, because of the downward turn of the economy over the years, amongst other reasons, involuntary singlehood has since been on the increase, especially amongst women. In view of the African perception that every normal person must get married, Nigerian single women go through a life that is largely characterised by a feeling of incompleteness and desperation for marriage. Since many of these women are members of the church, singlehood becomes a challenge to the church in Nigeria. This article postulated that the church in Nigeria can respond to this challenge through a reinterpretation of Paul's perception of celibacy in 1 Corinthians 7. It found that celibacy held sway in the church until the Reformation in the 16th century, which introduced negative attitudes towards the celibate life, especially in the Protestant churches. These attitudes have continued to date so much so that marriage is often considered to be the only normal course for adult Christians. In view of these negative attitudes, in Nigeria there is little space for Christians who would voluntarily want to choose the celibate life. The work concluded that this situation calls for a reinterpretation of Christian sexuality with emphasis on the value of celibacy outside the priesthood, and its equal status with marriage. The church in Nigeria has the responsibility to develop a Christian sexual theology to realise this purpose. A sexual theology of this type will be of immense benefit to the church as it makes marriage and celibacy complimentary to each other in the pursuit of the church's mission. In Nigeria, such a theology will enable Christian singles to see singlehood no more as a misfortune but as a possible calling to serve God.

\section{Acknowledgements Competing interests}

The author has declared that no competing interests exist.

\section{Authors' contributions}

The author declares that he is the sole author of this research article.

\section{Ethical considerations}

This article followed all ethical standards for research without direct contact with human or animal subjects.

\section{Funding information}

This research received no specific grant from any funding agency in the public, commercial or not-for-profit sectors.

\section{Data availability}

Data sharing is not applicable to this article as no new datawere created or analysed in this study.

\section{Disclaimer}

The views and opinions expressed in this article are those of the author and do not necessarily reflect the official policy or position of any affiliated agency of the author.

\section{References}

Ademiluka, S.O., 2019, 'Reading 1 Corinthians 7:10-11 in the context of intimate partner violence in Nigeria', Verbum et Ecclesia 40(1), 1-10. https://doi. org/10.4102/ve.v40i1.1926

Agana, A., 2018,'Is marriage for all? A theological reflection on the grammar of Genesis 2:18, 24', Asia-Africa Journal of Mission and Ministry 17, 90-110. https:// doi.org/10.21806/aamm.2018.17.05

Agazue, C., 2015, The role of a culture of superstition in the proliferation of religiocommercial pastors in Nigeria, Author House, Bloomington, IN.

Agazue, C., 2016, "'He told me that my waist and private parts have been ravaged by demons": Sexual exploitation of female church members by "prophets" in Nigeria', Dignity: A Journal on Sexual Exploitation and Violence 1(1), 1-16. https:// doi.org/10.23860/dignity.2016.01.01.10

Baloyi, M.E., 2010, 'Pastoral care and the agony of female singleness in the African Christian context', In die Skriflig 44(3 \& 4), 723-742. https://doi.org/10.4102/ids. v44i3/4.169

Barrett, C.K., 1968, A commentary on the First Epistle to the Corinthians, Harper \& Row, New York, NY

Barrett, C.K., 1971, A commentary on the First Epistle to the Corinthians, 2nd edn., A\&C Black, London.

Baumert, N.S.J., 1996, Woman and man in Paul: Overcoming a misunderstanding transl. P. Madigan \& L.M. Maloney, Michael Glazier, Collegeville, MN.

Bellani, D., Esping-Andersen, G. \& Nedoluzhko, L., 2017, ‘Never partnered: A multilevel analysis of lifelong singlehood', Demographic Research 37(1), 53-100. https://doi. org/10.4054/DemRes.2017.37.4

Bible Hub, 2004-2020, 'Commentaries on 1 Corinthians 7:7', Bible Hub viewed 15 June 2020, from https://biblehub.com/commentaries/1 corinthians/7-7.htm.

Burden, J., 2005, 'First Corinthians 7 and the role of celibacy in the mission of the church: Historic perspectives and modern application', Truett Journal of Church and Mission 3(2), 5-21.

Castelli, E.A., 1999, 'Paul on women and gender', in R.S. Kraemer \& M.R.D' Angelo (eds.), Women and Christian Origins, pp. 221-235, Oxford University Press, Oxford.

Clark, E.A., 1996, St. Augustine on marriage and sexuality, Catholic University of America, Washington, DC

Collins, R.F., 1999, First Corinthians, vol. 7, D.J. Harrington (ed.), Liturgical Press, Collegeville, PA.

Deming, W., 2004, Paul on marriage and celibacy: The Hellenistic background of 1 Corinthians 7, 2ndedn., Eerdmans, Grand Rapids, MI.

Dictionary.com, 2020, 'Celibacy', Dictionary.com, viewed 16 July 2020, from https:// www.dictionary.com/browse/celibacy.

Dodds, E.R., 2011, Pagan and Christian in the age of anxiety, Cambridge University Press, Cambridge.

Ekpendu, I.C., 2016, 'Celibacy: An exegetical study of 1 Cor. 7:1', International Journal of Research in Humanities and Social Studies 3(9), 29-33.

Fiore, B., 2003, 'Paul, exemplification, and imitation', in J.P. Sampley (ed.), Paul in the Greco-Roman world, pp. 228-257, Trinity Press International, Harrisburg.

Fitzmyer, J.A., 2008, First Corinthians, The Anchor Yale Bible, vol. 32, Yale University Press, New Haven, CT.

Frahm-Arp, M., 2012, 'Singleness, sexuality and the dream of marriage', Journal of Religion in Africa 42(4), 369-383. https://doi.org/10.1163/15700666-12341238

Isiugo-Abanihe, U., 2000, 'Female age at marriage and proportions marrying in Nigeria', African Population Studies 15(2), 43-65.

Keener, C.S., 1993, The IVP Bible background commentary: New Testament, Inter Varsity Press, Nottingham, IL.

King, D.D.M., 2011, 'The marriage debate and 1 Corinthians 7', MA thesis, Iliff School of Theology, Denver, CO.

Koons, C. \& Anthony, M., 1991, Single adult passages: Uncharted stories, Baker, Grand Rapids, MI.

Manasra, N.M., 2003, 'The effect of remaining unmarried on self-perception and mental health status: A study of Palestinian single women', PhD thesis, De Montfort University, Leicester.

Mangayi, L.C., 2014, 'Mobilising the local church for social justice and reconciliation: Theological/missiological reflections on the ministries of the Baptist Union of Southern Africa (1996-2011)', The South African Baptist Journal of Theology 23, 132-149.

Marty, M., 2008, Martin Luther: A life, Penguin Books, New York, NY.

McKnight, J., 1969, Apostolical Epistles and Commentary, Baker Book House, Grand Rapids, MI.

Moss, C.R. \& Baden, J.S., 2015, Reconceiving infertility: Biblical perspectives on procreation and childlessness, Princeton University Press, Princeton, NJ.

National Population Commission (NPC), 2009, Nigeria demographic and health survey 2008, NPC, Abuja. 
Ntoimo, F.C., 2012, 'Prevalence, determinants and consequences of spinsterhood in Lagos, Nigeria', PhD thesis, University of Ibadan.

Ntoimo, L.F.C. \& Isiugo-Abanihe, U., 2013, 'Patriarchy and singlehood among women in Lagos, Nigeria', Journal of Family Issues, 35(14), 1980-2008. https://doi. org/10.1177/0192513X13511249

Oderinde, O.A., 2013, 'A socio-religious perspective of late marriage and stigmatization of single adults and its impact on the Church in Nigeria', Review of European Studies 5(4), 165-171. https://doi.org/10.5539/res.v5n4p165

O'Loughlin, T., 2013, 'The Catholic Church and celibacy: An approach from historical theology', The Japan Mission Journal 67(3), 201-209.

O'Reggio, T., 2012, 'Martin Luther on marriage and family', Faculty Publications 20 viewed 03 June 2020, from http://digitalcommons.andrews.edu/church-historypubs $/ 20$.

Shuzhuo, L., Qunlin, Z., Xueyan, Y. \& Attané, I., 2010, 'Male singlehood, poverty and sexuality in rural China: An exploratory survey', Population 65(4), 679-693. https://doi.org/10.3917/pope.1004.0679

Ozment, S., 1993, 'Re-inventing family life', Christian History 12(3), 22-34.

Reed, D.A., 2013, 'Paul on marriage and singleness: Reading 1 Corinthians with the Augustan marriage laws', PhD. thesis, Toronto School of Theology, Toronto, ON.
Studylight.org, 2001-2020, 'Commentaries on 1 Corinthians 7:7', Studylight.org, viewed 15 June 2020, from https://www.studylight.org/commentary/1 corinthians/7-7.html.

Varnell, B., 2016, 'It is good: Theological reflections on celibacy and sexual life', Honours thesis, Baylor University, Waco, TX.

Vaverek, T.V., 2005, 'A Catholic view of celibacy: A response to Josh Burden', Truett Journal of Church and Mission 3(2), 22-27.

Voice of the Faithful, n.d., 'A brief history of celibacy', Voice of the Faithful, 1-6, viewed 11 July 2010, from http://www.votf.org/Celibacy-Ordination/Celibacy_ BriefHistory.pdf.

Webster, M., 2020a, 'Singlehood',Merriam-Webster Dictionary, viewed 06 June 2020 from https://www.merriam-webster.com/dictionary/singlehood.

Webster, M., 2020b, 'Celibacy', Merriam Webster Dictionary, viewed 16 July 2020, from https://www.merriam-webster.com/dictionary/celibacy.

Witte, J., Jr., 2009, 'Marriage and family life', in H.J. Selderhuis (ed.), The Calvin handbook, pp. 455-456, Erdmans, Grand Rapids, MI.

Zwang, J., 2004, 'Perceptions and attitudes towards late marriage and premarital fertility in rural South Africa: A study on social changes and health risks amon young adults', IFAS working paper series / Les Cahiers de I' IFAS, 2004, 4, 61p, hal00786290. 